\title{
Oil Price And Real Exchange Rate: The Case Of India
}

Neetu Kaushik, University of New Haven, USA

Raja Nag, New York Institute of Technology, USA

Kamal P. Upadhyaya, University of New Haven, USA

\begin{abstract}
This paper studies the effect of oil price change on the real exchange rate between the Indian rupee and the U.S. dollar. For that, a model is developed which is based on a monetary model of exchange rate which incorporates the real GDP, real money balances, and the interest rates of both the home and foreign country and the real price of the crude oil. Quarterly time series data from 1996 to 2012 is used. Before estimating the model, the time series properties of the data are diagnosed in order to ensure the stationarity of the data. The data series are found to be integrated of order one and the null hypothesis of no cointegration is rejected. Therefore an error correction model is developed and estimated. The estimated results suggest that there is no detectable effect of oil price change on the real exchange rate between the Indian rupee and the U.S. dollar.
\end{abstract}

Keywords: India; Oil Price; Real Exchange Rate; Error Correction Model

\section{INTRODUCTION}

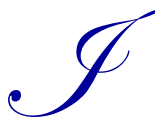

ndia is the fourth largest oil importer in the world. It imports in excess of 3 million barrels of petroleum per day. From the fiscal year 2005-2006 to 2010-2011, on average, the import of crude oil has been equivalent to about $40 \%$ of the country's total export. In the fiscal year, 2011-2012, it increased to over $53 \%$ of the total export, a staggering $\$ 160$ billion in monetary value. One of the obvious reason for this increase is the upsurge in the use of modern technology in production in both agricultural as well as non-agricultural sectors, including a phenomenal rise in the use of the modern mode of transport such as automobiles, motorbikes, etc., which is associated with the growth rate of the economy. Another significant reason is the rising crude oil price in the international market. Given that the demand for petroleum is relatively inelastic, an increase in the price of petroleum is translated into greater amount in terms of import value.

The oil contracts are denominated in US dollars in the world market. Therefore a change in the price of oil can have a significant impact on the demand as well as on the supply of foreign exchange. There are several studies that have examined the relationship between oil price and the currency exchange rate. Krugman (1980) in his study on the impact of oil price on the U.S. dollar finds that an increase in the price of oil has a different impact in its value in the short-run and in the long-run. While the dollar would appreciate in the short-run with an increase in oil prices, yet it would depreciate in the long-run. Throop (1993) studied the sources of exchange rate between the U.S. dollar and other major currencies in the post 1973 flexible rate experience. In his findings, he concludes that the change in real price of oil is one of the main factors affecting the exchange rate stability; the other two factors being the productivity growth and the government budget deficits. Amano and Nordan (1998) document a robust relationship between the real domestic price of oil and the real effective exchange rates for Germany, Japan, and the U.S.A. in their study. Akram (2004) in his study finds a negative relationship between oil prices and the value of the Norwegian currency exchange rate, Norway being an oil exporting country his finding seems to be implausible. Chen and Chen (2007) investigated the long run relationship between real oil prices and real exchange rates by using a monthly panel data from 1972 to 2005 of G7 countries and found that these two variables are co-integrated. They also suggest that there is a link between the real price of oil and the real exchange rate. 
There are some interesting papers that have studied the link between the oil price and currency exchange rate in developing countries. One such study is by Coleman, Cuestas, and Mourelle (2011), which investigated the importance of real oil price as a determinant of real exchange rates for a pool of African countries and suggest that the shocks in the real price of oil are important determinants of real exchange rates. Dogan et al. (2012) studied the relationship between the real price of oil and the real exchange rate in Turkey using monthly data from 2001 to 2011. Their findings suggest that the oil price movement does affect the real exchange rates. Huang and Feng (2007) on the other hand find that in China real oil price shocks lead to minor appreciation of the long-term real exchange rate probably due to China's lesser dependence on oil imports but still they account a noticeable relationship. There are few studies on this issue also about India. For example, Ghosh (2011) using daily data from 2007 to 2008 revealed that an increase in the oil price leads to the depreciation of Indian currency vis-à-vis the U.S. dollar. He also found that oil price shocks have a permanent effect on the exchange rate volatility. Since Ghosh's study is confined with the data for only a year, it does not provide the long run relationship between the oil price and exchange rate.

India has moved from fixed exchange regime to floating exchange regime. Because of this, oil price changes can have important implications on the value of its currency. Given the dearth of the study on the relationship between the real price of oil and the real exchange rate in India, the primary objectives of this paper are: (1) to estimate the effect of oil price change on the exchange rate between the Indian rupee and the U.S. dollar, and, (2) to analyze these results both in context of the short run and as well as the long run.

The organization of the paper is as follows: Section two presents theoretical background and methodology; empirical findings and analyses are presented in section three, and our summary and conclusions are reported in section four.

\section{THEORETICAL BACKGROUND AND METHODOLOGY}

Most of the studies mentioned above just use the co-integration test in order to investigate the relationship between the real oil price and the real exchange rate, without any established theoretical background of exchange rate determination. In this paper, we develop and estimate a model which is based primarily on the monetary model of exchange rate (for details, see Upadhyaya, 1994; Upadhyaya \& Pradhan, 2006). The model that is developed in order to estimate the impact of oil price movement on the real exchange rate of Indian rupee is as follows:

$$
\begin{gathered}
\log R E R=c_{0}+c_{1} \log m+c_{2} \log m^{*}+c_{3} \log y+c_{5} \log y^{*}+c_{5}\left(i-i^{*}\right)+c_{6} \log R P O I L+u \\
\mathrm{c}_{1}>0 ; \quad c_{2}<0 ; \quad c_{3}>0 ; \quad c_{4}<0 ; \quad c_{5}<0 ; \quad c_{6}>0
\end{gathered}
$$

In Equation 1, RER, the real exchange rate, (Indian rupee per dollar) is defined as nominal exchange rate times the ratio of foreign price index to domestic price index; $m$ represents the real money balances; $y$ is real GDP; $i$ represents the interest rate and RPOIL stands for price of oil in real term. The asterisk * indicates the foreign country. U.S.A. is considered as the foreign country in this study, and hence * represents the United States. As indicated above the coefficient of $\log m$ is expected to be positive as an increase in the domestic money balances is expected to depreciate the domestic currency. Likewise, an increase in the foreign money balances is likely to depreciate their currency implying that the domestic currency will appreciate; hence its coefficient is expected to be negative. An increase in domestic output is expected to appreciate the domestic currency and an increase in foreign output is expected to depreciate the domestic currency as mentioned above. Finally, the coefficient of interest in our model is the coefficient of $\log$ RPOIL. Since, an increase in the price of oil increases the demand for foreign currency (in order to make payment for the import) then the domestic currency theoretically should depreciate. If this coefficient is positive and statistically significant it will imply that the increase in the price of oil depreciates the domestic currency.

Our study is based on the quarterly time series data from 1996 to 2012 with a sample of 68 observations. All the data are derived from various issues of International Financial Statistics published by the International Monetary Fund (IMF), except the Indian crude oil price. The Indian crude oil price has been extracted from World Bank (www.data.worldbank.org). 


\section{ESTIMATION AND EMPIRICAL RESULTS}

Macroeconomic time series data contain unit root and are not stationary. The use of non-stationary data produces spurious results. Therefore, before carrying out the estimation of Equation (1) it is important to test the stationarity of the data series to avoid spurious results. Following Nelson and Plosser (1982), an augmented DickeyFuller test is conducted on the data series to ensure the stationarity. This involves estimating the following regression and carrying out unit root tests:

$\Delta X_{t}=\alpha+\rho_{t}+\beta X_{t-1}+\sum_{i=1}^{n} \lambda_{i} \Delta X_{t-i}+\varepsilon_{t}$

In Equation (2) $X$ is the variable under consideration, $\Delta$ is the first difference operator, $t$ is a time trend, and $\varepsilon$ is a stationary random error term. If the null hypothesis, that $\beta=0$, is not rejected the variable series contains a unit root and is non-stationary. The optimal lag length in the above equation is identified by ensuring that the error term is white noise error term. Second, in addition to the augmented Dickey-Fuller test, a Phillips-Perron test (Phillips-Perron 1988) is also conducted to ensure the stationarity of the data series. The Phillips-Perron test uses non-parametric correction to deal with any correlation in the error terms. As the results in Table 1 point out, both the Dickey-Fuller test and the Phillips-Perron test indicate that all the data series are non-stationary in level form. Therefore the same tests are performed for first-differences. The test results (see Table 1) indicate that all the series are stationary in first-difference form.

Table 1: Unit Root Test

\begin{tabular}{|c|c|c|c|c|}
\hline \multirow[b]{2}{*}{ Variable } & \multicolumn{2}{|c|}{ ADF Test } & \multicolumn{2}{|c|}{ P-P Test } \\
\hline & Level & FD & Level & FD \\
\hline$\Delta \log \mathrm{m}$ & -1.59 & $-7.42 * * *$ & -1.58 & $-8.66 * * *$ \\
\hline $\log m^{*}$ & -2.12 & $-7.22 * * *$ & -2.22 & $-6.91 * * *$ \\
\hline $\log y$ & -2.42 & $-3.77 * *$ & -2.42 & $-8.63 * * *$ \\
\hline $\log y^{*}$ & -1.95 & $-3.60 * *$ & -2.07 & $-9.30 * * *$ \\
\hline$\left(i-i^{*}\right)$ & -2.11 & $-8.15 * * *$ & -2.11 & $-9.14 * * *$ \\
\hline $\log R P O I L$ & -2.89 & $-6.91 * * *$ & -2.89 & $-7.92 * * *$ \\
\hline
\end{tabular}

Note: ** significant at $5 \%$ critical level; *** significant at $1 \%$ critical level.

Having established the stationarity of the data, the Johansen (1988) approach is used to test for a long-run equilibrium relationship among the variables. This involves testing the cointegrating vectors. Consider a $p$ dimensional vector autoregression,

$X_{t}=\sum_{i=1}^{k} \pi_{t} X_{t-i}+c+\varepsilon_{t}$

which, can be written as,

$\Delta X_{t}=\sum_{i=1}^{k} \Gamma_{i} X_{t-k}-\pi X_{t-k}+c+\varepsilon_{t}$

where,

$\Gamma_{i}=-I+\pi_{1}+\pi_{2}+\ldots \ldots \ldots+\pi_{t}$

$i=1,2, \ldots \ldots, k-1$ and

$\pi=I-\pi_{1}-\pi_{2}-\ldots . .-\pi_{\mathrm{k}}$ 
and, where $p$ is the number of variables under consideration. The matrix $\pi$ captures the long run relationship between $p$ variables, and this can be decomposed into two matrices, $A$ and $B$, such that $\pi=A B^{\prime}$. $A$ is interpreted as the vector error correction parameter and $B$ as cointegrating vectors. This procedure is used to test the existence of a long run relationship between all the variables in Equation (1). The estimated results are reported in Table 2. The test result rejects the null of no cointegration. Therefore, following Engle and Granger (1987) an error correction model is developed which is as follows:

Table 2: Johansen's Cointegration Test

\begin{tabular}{|l|c|c|c|}
\hline \multicolumn{1}{|c|}{$\mathbf{H}_{\mathbf{0}} \mathbf{0}$} & Eigenvalue & Trace Statistics & Critical value (5\%) \\
\hline$r \leq 0$ & 0.541 & $166.31^{*}$ & 125.61 \\
\hline$r \leq 1$ & 0.454 & $115.66^{*}$ & 96.75 \\
\hline$r \leq 2$ & 0.372 & $76.322^{*}$ & 69.82 \\
\hline$r \leq 3$ & 0.293 & 46.04 & 47.85 \\
\hline$r \leq 4$ & 0.220 & 23.48 & 29.80 \\
\hline$r \leq 5$ & 0.101 & 7.35 & 15.49 \\
\hline$r \leq 6$ & 0.007 & 0.434 & 3.84 \\
\hline
\end{tabular}

Note: Significant at $5 \%$ critical level

$\Delta \log R E R=c_{0}+c_{1} \Delta \log m+c_{2} \Delta \log m^{*}+c_{3} \Delta \log y+c_{5 \Delta} \log y^{*}+c_{5}\left(i-i^{*}\right)+c_{6} \Delta \log R P O I L+c_{7} E C+u$

In Equation (7), EC is the error correction term which is nothing but the lagged values of the error terms derived from the estimation of Equation (1). Estimation of Equation (7) is as follows:

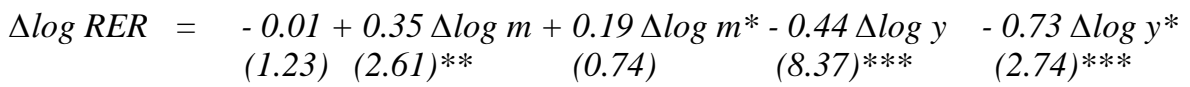

$$
\begin{aligned}
& +0.01 \Delta\left(i-i^{*}\right)+0.02 \Delta \log R P O I L-0.44 E C \\
& \text { (0.94) (1.05) (4.95)*** } \\
& \text { Adj. } R^{2}=0.584 \quad F=14.23 \quad \text { D.W. }=1.99 \quad n=67
\end{aligned}
$$

Note: Figures in the parentheses are t-values for the corresponding coefficients. $* * *, * *$, significant at $1 \%$ and $5 \%$ critical level.

In Equation (8) estimated coefficients of both $\log m$ and $\log y$ carry theoretically consistent sign and they are statistically significant as well. The estimated coefficients suggest that a $1 \%$ change in the growth of domestic money supply depreciates the rate of currency depreciation by 0.35 percent. Likewise, an increase in the rate of growth of domestic output (real GDP) by 1 percent leads to a 0.44 percent change in the currency appreciation rate.

The coefficient of foreign money supply carries a theoretically wrong sign but it is statistically insignificant. Likewise the coefficient of interest rate differential $(i-i *)$ carries a wrong sign but it is statistically not significant. The coefficient of foreign output (foreign real GDP) carries a negative and statistically significant coefficient as opposed to our expectation. One plausible explanation for this could be that when there is an economic growth in foreign country their import demand (domestic export) increases. This in turn increases the demand for domestic currency (Indian rupees) in the foreign exchange market which ultimately appreciates the domestic currency.

The focus of this study is the coefficient of $\log$ RPOIL. The positive coefficient of this variable suggests that an increase in the oil price leads to the depreciation of Indian rupee. The coefficient of the error correction term is negative and statistically significant indicating that any deviation of the dependent variable in current period due to any changes in the independent variable(s) is adjusted back to equilibrium over the period of time. The significant coefficient of $E C$ also indicates that the variables in the model are cointegrated in the long run, implying there exists a long run relationship between the real oil price and the real exchange rate. The problem however, is that the coefficient is not significant. Based on this fact we argue that, in case of India, any movement in oil price does not have any detectable effect on the real exchange rate of Indian rupee. 


\section{SUMMARY AND CONCLUSION}

This paper estimates the effect of oil price change on the real exchange rate of Indian rupee. In order to do so an empirical model is developed based on the monetary model of exchange rate. The variables incorporated in the model include domestic real money balances, foreign money balances, domestic output and foreign output, interest rate differentials between the domestic country and foreign country, and the real domestic price of oil, with real exchange rate as the dependent variable. The nominal exchange rate is defined as rupees per dollar and the real exchange rate is calculated using the nominal exchange rate times the foreign consumer price index to domestic consumer price index. U.S.A. is assumed to be the foreign country. Quarterly time series data from 1996 to 2012 is used. Before estimating the model the time series properties of the data are diagnosed using the standard unit root as well as the cointegration tests. All the data are found to be stationary at the first difference level and the hypothesis of no cointegration is rejected. Therefore an error correction model is developed and estimated. The estimated results suggest that the domestic real money balances, domestic real GDP, and foreign real GDP are the significant determinants of real exchange rate in India. The oil price though seems to have a depreciating effect on the Indian rupee but the effects seem to be undetectable (as indicated by the statistically insignificant coefficient).

\section{AUTHOR INFORMATION}

Dr. Neetu Kaushik is an Adjunct Professor of Economics at the University of New Haven. Her areas of research include international economics, development economics, and South Asian economy. Her recent work has appeared in the Journal of Applied Business Research. E-mail: Nkaushik@ newhaven.edu

Dr. Raja Nag is a Professor of Finance at the School of Management of New York Institute of Technology. His research interests include SEOs, IPOs, REITs, asset valuation, capital structure, and corporate finance. He has published papers in Real Estate Economics, Journal of Real Estate Finance \& Economics, Real Estate Finance, Journal of Real Estate Portfolio Management, Journal of Business and Economics Research, Journal of Applied Business Research, International Business and Economics Research Journal, and Applied Financial Economics. He is ad hoc referee of several peer reviewed journals, and has presented in numerous conferences. E-mail: dnag@nyit.edu (Corresponding author)

Dr. Kamal P. Upadhyaya is a Professor of Economics at the University of New Haven. His recent works have appeared in Applied Economics, European Journal of Development Research, Journal of Applied Business Research, and Southern Economic Journal. He serves on the editorial board of Environmental Economics and ISSR Economics - An Open Access Journal. Dr. Upadhyaya's works are widely cited in academic papers, books, and in dissertations and theses. E-mail: Kupadhyaya@ newhaven.edu

\section{REFERENCES}

1. Akram, Q. F. (2004). Oil prices and exchange rates: Norwegian evidence. Econometrics Journal, 7, 476504.

2. Amano, R. A., \& van Norden, S. (1998). Exchange rates and oil prices. Review of International Economics, 6, 683-694.

3. Chen, S., \& Chen, H. (2007). Oil prices and real exchange rates. Energy Economics, 29(3), 390-404.

4. Coleman, S., Cuestas, J. C., \& Mourelle, E. (2011). Investigating the oil price-exchange rate nexus: Evidence from Africa. (Working Papers 2011015). The University of Sheffield, Department of Economics, revised May 2011.

5. Dogan, S., Ustaoglu, M., \& Demez, S. (2012). Relationship between real oil price and real exchange rate: The case of Turkey. Procedia - Social and Behavioral Sciences, 58(October), 1293-1300.

6. Engle, R., \& Granger, C. (1987). Cointegration and error correction: Representation, estimation, and testing. Econometrica, 55, 251-76.

7. Ghosh, S. (2011). Examining crude oil price - Exchange rate nexus for India during the period of extreme oil price volatility. Applied Energy, 88, 1886-1889.

8. Huang, Y., \& Feng, G. (2007). The role of oil price shocks on China's real exchange rate. China Economic Review, 8, 403-416. 
9. Johansen, S. (1988). Statistical analysis of cointegration vectors. Journal of Economic Dynamics and Control, 12, 231-254.

10. International Monetary Fund (various issues). International financial statistics, IMF, Washington, D.C.

11. Krugman, P. (1980). Oil and the dollar. (NBER Working Paper Series 554).

12. Nelson, C. R., \& Plosser, C. I. (1982). Trends and random walks in macroeconmic time series: Some evidence and implications. Journal of Monetary Economics, 10(September), 139-162.

13. Phillips, P. C., \& Perron, P. (1988). Testing for a unit root in time series regression. Biometrika, 75, 335346.

14. Throop, A. (1993). A generalized uncovered interest parity model of exchange rates. Federal Reserve of San Francisco Economic Review, 2, 3-16.

15. Upadhyaya, K. P., \& Pradhan, G. (2006). Another empirical look at the monetary approach to exchange rate determination: The case of G-7 countries. Issue \# 69. Briefing Notes in Economics, 2006, pp. 1-9.

16. Upadhyaya, K. P. (1994). Monetary model of exchange rate determination: evidence from the Canadian/U.S. dollar exchange rate during eighties. The Indian Economic Journal, 41(January-March 1994), 158-164.

17. World Bank. Retrieved from http://data.worldbank.org/ 